\title{
Enteropathogens in acute diarrhea: a general practice-based study in a Nordic country
}

\author{
I. Hilmarsdóttir • G. E. Baldvinsdóttir • \\ H. Harðardóttir $\cdot$ H. Briem • S. I. Sigurðsson
}

Received: 8 June 2011 / Accepted: 17 October 2011 / Published online: 5 November 2011

(C) Springer-Verlag 2011

\begin{abstract}
The epidemiology of infectious diarrhea influences the microbiological investigation of the disease, and is best elucidated through prospective studies. We undertook such a study in a Nordic country. Patients of all age groups who had acute diarrhea were recruited prospectively from general practice clinics in Iceland. They completed a questionnaire and provided stool samples for the detection of pathogenic viruses, bacteria, and parasites. Of the 464 recruited patients, 211 (45\%) had 224 infections. The most common pathogens were calici- and rotaviruses ( $23 \%$ and $18 \%$ of 224 infections, respectively), Campylobacter jejuni (17\%), Cryptosporidium species (12\%), and Salmonella serotypes (10\%). Other agents found were Giardia lamblia, astro- and adenoviruses, and Yersinia enterocolitica. Viral pathogens were associated with vomiting, illness for $\leq 7$ days, and younger age groups,
\end{abstract}

I. Hilmarsdóttir $(\bowtie) \cdot H$. Harðardóttir

Department of Microbiology,

Landspítali-The National University Hospital of Iceland,

Barónsstígur,

101, Reykjavík, Iceland

e-mail: ingibjh@landspitali.is

G. E. Baldvinsdóttir

Department of Virology,

Landspítali-The National University Hospital of Iceland,

Reykjavík, Iceland

H. Briem

Directorate of Health,

Reykjavík, Iceland

S. I. Sigurðsson

Health Care Clinics of Reykjavík,

Reykjavík, Iceland

I. Hilmarsdóttir $\cdot$ H. Briem

University of Iceland,

Reykjavík, Iceland while bacterial pathogens were associated with fever, rectal pain, and local or foreign travel, and parasitic pathogens with illness for $>7$ days. Detection rates for viral infections in the elderly and for Cryptosporidium species were higher than expected. Our study indicates the existence of regional differences in pathogen prevalence that should be taken into account when implementing guidelines for stool testing in patients with acute diarrheal disease.

\section{Introduction}

Infectious diarrhea remains an important disease in the developed world, in spite of high living standards and education levels. Studies report an incidence of 19-83 cases/100 person-years [1-5]. This variation may reflect differences in epidemiology, patients' approach to the illness, physicians' practices, and laboratory tests used. Only $17-20 \%$ of patients seek medical care and less than $30 \%$ of these have laboratory tests [1, 3-5]. Since symptoms and risk factors for bacterial diarrhea are overrepresented among consulting patients [6] and lead to selective stool testing, the relative contribution of diarrhea pathogens in official data is usually biased towards bacteria such as Campylobacter species and Salmonella serotypes [1].

While patients and physicians are increasingly aware of bacterial causes in all age groups, partly because of official data and foodborne outbreaks, the same may not be true for viral and parasitic pathogens. The relative contribution of the various organisms to diarrheal disease among patients who seek healthcare can only be clarified through prospective studies which address all major pathogens $[7,8]$. The resulting knowledge about regional epidemiology has a role in guiding requests for stool tests, along with other important factors such as patients' symptoms, underlying 
conditions, occupation, travel, and outbreak situations. The negative impact of diarrheal disease on the individual and the high societal cost due to healthcare, lost productivity [9, 10], and food recalls warrant an optimization of the healthcare approach to the problem.

This study was initiated in order to obtain information about the epidemiology of enteric infections among patients of all age groups who consult with general practitioners in a Nordic country and to evaluate the association between individual pathogens and symptoms. The results are expected to influence the choice of stool test requests by physicians and testing methods in the laboratory.

\section{Materials and methods}

\section{Patients}

The study was conducted from September 2003 to December 2007 at six general practice (GP) clinics in Iceland. Patients of all ages were recruited at three clinics in two of Reykjavík's suburbs (Kópavogur and Seltjarnarnes), and three on Iceland's west coast (Akranes), southwest part (Selfoss), and north coast (Akureyri). Together, they service a population of about 69,000 habitants. The inclusion criterion was acute diarrhea of $\leq 15$ days' duration, as defined by the patients. Exclusion criteria were the use of systemic antibiotics after the diarrhea started, known immunosuppression, history of a chronic diarrhea due to noninfectious causes, and diarrhea that started during hospitalization. Patients or minors' guardians signed an informed consent form and completed a self-administered questionnaire on symptoms and other patient-related factors, and known diarrheal illness among family members, friends, or co-workers. Patients provided one stool specimen, taken within three days from the visit to the GP Clinic, which was divided between a vial containing Cary-Blair transport medium for bacterial culture and two dry vials for virology and parasitology tests. Specimens were stored in a refrigerator and transferred within three days from collection to the laboratories at Landspítali. Information about age distribution among the Icelandic population was obtained from Statistics Iceland (http://www.statice.is/).

\section{Microbiology}

Salmonella serotypes, Shigella species, and Yersinia enterocolitica were detected by inoculating stool directly and after overnight culture in selenite enrichment broth on MacConkey, Hektoen, and Yersinia Selective (Oxoid, Basingstoke, England) media that were incubated for 16$72 \mathrm{~h}$. Suspect colonies were screened in Kligler iron and phenylalanine agars. API 20E (bioMérieux, Marcy l'Étoile,
France) and serotyping (Salmonella antisera from Dade Behring/Siemens Healthcare Diagnostics, Marburg, Germany, Statens Serum Institut, Copenhagen, Denmark, and BD Difco Shigella Antisera Poly, Maryland, USA) were used for further identification. Campylobacter species were detected on Skirrow's selective medium incubated at $42^{\circ} \mathrm{C}$ for $48-72 \mathrm{~h}$ and identified by hippurate and indoxyl acetate hydrolysis and API Campy biochemical tests (bioMérieux). Escherichia coli $\mathrm{O} 157$ was detected on MacConkey and SorbitolMacConkey media incubated for 16-24 h, and identified by API 20E and a latex agglutination test for the O157 serotype (Dry Spot, Oxoid).

Liquid stool specimens were tested for Clostridium difficile toxins $\mathrm{A}$ and $\mathrm{B}$ by the use of ProSpecT ${ }^{\circledR}$ Clostridium difficile Toxin A/B Microplate Assay (Oxoid).

Specimens were tested for parasites after formalin ethyl acetate concentration in the Midi Parasep ${ }^{\circledR}$ concentration kit (DiaSys, Holzheim, Germany). The sediment was examined through a light microscope and treated with Merifluor ${ }^{\circledR}$ Cryptosporidium/Giardia fluorescent antibody test for the detection of Giardia lamblia and Cryptosporidium species (Meridian Bioscience, Cincinnati, OH, USA). Blastocystis hominis was considered to be a potential pathogen if it is present in large numbers in a stool sample and no other pathogens were found.

Adenovirus, astrovirus, and rotavirus were tested by the immunoassays IDEIA ${ }^{\circledR}$ Adenovirus, IDEIA ${ }^{\circledR}$ Astrovirus, and IDEIA $^{\circledR}$ Rotavirus (DAKO, Glostrup, Denmark). Human caliciviruses were detected by reverse-transcription polymerase chain reaction (RT-PCR) assay using primers targeting the polymerase region of the virus genome (3D), as previously described [11]. A $10 \%$ suspension of stool sample was prepared in Hanks' BSS and viral RNA was extracted using the HighPure extraction kit (Roche Diagnostics, Mannheim, Germany). Three sets of primers were used: reverse primer NVp110 (nt position 4865-4884) and forward primers NVp36 (nt position 4487-4501), NVp69 (nt position 47334752) or NI (nt position 4768-4788) [11]. The PCR products were separated by polyacrylamide gel electrophoresis, performed in $4-20 \%$ gradient minigels (Mighty Small II, Hoefer, San Francisco, CA, USA) of acrylamide:bis-acrylamide, in a ratio of 29:1. The products were visualized by ethidium bromide staining.

Information about the diagnostic yield of routine stool tests was obtained from the Departments of Microbiology and Virology at Landspítali.

The microbiology laboratories participate in both the United Kingdom National External Quality Assessment Service (UKNEQAS; http://www.ukneqas.org.uk) and the External Quality Assurance in Laboratory Medicine in Sweden (EQUALIS; http://www.equalis.se) external proficiency program for bacterial, parasitical, and viral pathogens. 
Statistical methods

For the purpose of this study, we grouped related microorganisms into three main pathogen groups: viral, bacterial, and parasitic pathogens. The Pearson Chi-square test was used to test the association of these groups with the following patient-related factors: travel history, diarrheal illness in the patient's entourage, and main age groups defined as $<1$ year, $1-4$ years, 5-14 years, 15-29 years, 30-59 years, and $\geq 60$ years of age, and to compare the diagnostic yield of stool samples from study patients and other patients tested in the laboratory; a $p$-value $<0.05$ was considered to be significant.

Multiple logistic regression analysis was used on the available data in order to examine the association of each pathogen group with age, duration of diarrheal illness before the visit to the GP Clinic, and symptoms; patients with multiple infections were excluded. For this purpose, the patients were divided into 5-year age groups, and the symptoms examined were fever, vomiting, bloody diarrhea, abdominal pain, and rectal pain. All patient-related variables were stepwise selected into the model with an entry testing based on the significance of the score statistic and a removal testing based on the likelihood ratio statistic (level for entry 0.05 and removal 0.1 ). An estimate of the effect of each of the selected variables is presented as an adjusted odds ratio (OR) with a 95\% confidence interval (CI). For processing the data, the SPSS 17 software package was used. The level of significance was set at 0.05 .

In order to assess our results in the light of findings from comparable studies, data about selected pathogens and age groups were extracted from two published European studies. Recruitment into both studies was done among patients who consulted GP Clinics. The English study included patients with gastroenteritis for $\leq 2$ weeks' duration $[7,12]$, and the Dutch study included those individuals who had diarrhea associated with other symptoms, but without a time limit on the duration of illness [8]. In addition, we included data from a third study in which stored stool specimens from the English study were re-examined with PCR methods [12].

The study was approved by Iceland's National Bioethics Committee.

\section{Results}

Out of 464 patients who were included from September 2003 to December 2007, 248 (53.4\%) were women. The median age was 30 years (range $0-83$ ). The enrollment rate was constant from year to year, and the average monthly rate varied from 3.5 to 11.8 patients. Inclusion peaks were observed in late winter and spring during the years 2005 2007, but not in 2004.

Two hundred and twenty-four infections were detected in 211 out of the 464 patients $(45.5 \%)$; 12 patients had $2-3$ infections each. The proportion of patients who had any infection detected or positive tests for viral or bacterial pathogens did not differ significantly between the years. The same was not true for parasitic pathogens that were significantly more frequent in 2003, when $28.6 \%$ of patients tested positive, as opposed to a rate of $5.5-13.7 \%$ for the remaining study years $(p=0.001)$. Nine out of the 27 cases with Cryptosporidium species occurred in the 35 patients recruited in 2003, probably as a part of a small outbreak that was seen mainly in the Reykjavík area.

The proportional sizes of the age groups in the study were representative for those in the general population, with the exception of children. Seven percent of the general population belonged to the age group $0-4$ years and $15 \%$ to the age group 5-14 years, whereas these groups represented 22 and $7 \%$ of the study population, respectively.

Table 1 shows all of the microorganisms that were detected in the study and Fig. 1a shows the proportions of the main pathogen groups, bacteria, parasites, and viruses, within each age group. Caliciviruses were the most commonly detected organisms, followed by rotaviruses and Campylobacter species. The frequency of each pathogen group differed significantly among the main age groups ( $p=0.005$ for viruses and bacteria, $p=0.032$ for parasites). Viral infections were seen more commonly in the young and the elderly, bacterial infections in adults under 60 years of age, and parasitic infections in the latter age group and school children (Table 1 and Fig. 1a). Clostridium difficile toxin was detected in two out of the 79 patients who had liquid stools; neither of them had used antibiotics or had been hospitalized within four weeks before the onset of illness. E. coli $\mathrm{O} 157$ was not found, and it seems to be rare in Iceland. For the past 20 years, we have identified only 44 cases, 17 of which were outbreak-related.

A multivariate analysis of the association of illness characteristics and age with the main pathogen groups was done for the 452 patients who had a simple infection (one pathogen detected) or no detectable infection (Table 2). Viral pathogens were shown to be associated with vomiting, illness for $\leq 7$ days, and the younger age groups (OR 0.8 , 95\% CI 0.88-0.99 for incremental age). Bacterial pathogens were associated with rectal pain and fever, and parasitic pathogens with illness for $>7$ days. In addition, there were tendencies towards an association between bacteria and the older age groups (OR 1.09, 95\% CI 1.0-1.18 for incremental age), and parasites and abdominal pain. The decision to divide the duration of illness at the 7-day limit was supported by the similarity between the subgroups of shorter time intervals (Fig. 2). Bloody stools were not found to be 
Table 1 Microorganisms detected in the various age groups during the study

\begin{tabular}{|c|c|c|c|c|c|c|}
\hline \multirow{2}{*}{$\begin{array}{l}\text { Microorganisms } \\
\text { (number of patients) }^{\mathrm{b}}\end{array}$} & \multicolumn{6}{|c|}{ Number of patients (\%) who tested positive, including patients with mixed infections ${ }^{a}$} \\
\hline & $\begin{array}{l}0-4 \text { years } \\
(n=103)\end{array}$ & $\begin{array}{l}5-14 \text { years } \\
(n=33)\end{array}$ & $\begin{array}{l}15-29 \text { years } \\
(n=88)\end{array}$ & $\begin{array}{l}30-59 \text { years } \\
(n=191)\end{array}$ & $\begin{array}{l}\geq 60 \text { years } \\
(n=49)\end{array}$ & All $(n=464)$ \\
\hline \multicolumn{7}{|l|}{ Bacteria (62) } \\
\hline Campylobacter spp. & $4(3.9)$ & $1(3.0)$ & $11(12.5)$ & $19(9.9)$ & $3(6.1)$ & $38(8.2)$ \\
\hline Salmonella serotypes & $1(1.0)$ & $1(3.0)$ & $4(4.5)$ & $14(7.3)$ & $1(2.0)$ & $21(4.5)$ \\
\hline Yersinia spp. & $1(1.0)$ & $0(0.0)$ & $1(1.1)$ & $1(0.5)$ & $0(0.0)$ & $3(0.6)$ \\
\hline \multicolumn{7}{|l|}{ Parasites (45) } \\
\hline Giardia lamblia & $0(0.0)$ & $3(9.1)$ & $1(1.1)$ & $11(5.8)$ & $2(4.1)$ & $17(3.7)$ \\
\hline Cryptosporidium spp. & $4(3.9)$ & $2(6.1)$ & $11(12.5)$ & $10(5.2)$ & $0(0.0)$ & $27(5.8)$ \\
\hline Blastocystis hominis & $0(0.0)$ & $0(0.0)$ & $0(0.0)$ & $1(0.5)$ & $0(0.0)$ & $1(0.2)$ \\
\hline \multicolumn{7}{|l|}{ Viruses (113) } \\
\hline Adenovirus & $4(3.9)$ & $1(3.0)$ & $2(2.3)$ & $1(0.5)$ & $1(2.0)$ & $9(1.9)$ \\
\hline Astrovirus & $6(5.8)$ & $2(6.1)$ & $1(1.1)$ & $4(2.1)$ & $2(4.1)$ & $15(3.2)$ \\
\hline Calicivirus & $14(13.6)$ & $2(6.1)$ & $10(11.4)$ & $16(8.4)$ & $9(18.4)$ & $51(11.0)$ \\
\hline Rotavirus & $13(12.6)$ & $5(15.2)$ & $4(4.5)$ & $15(7.9)$ & $4(8.2)$ & $41(8.8)$ \\
\hline
\end{tabular}

${ }^{a}$ Nine patients had calicivirus associated with adenovirus (one case), rotavirus (two cases), C. jejuni (two cases), Cryptosporidium spp. (one case), G. lamblia (two cases), or C. jejuni and Cryptosporidium spp. (one case). Two patients had Salmonella enterica serovar Enteritidis associated with S. enterica Typhimurium or astrovirus, and one patient had C. jejuni and Cryptosporidium spp.

${ }^{\mathrm{b}}$ C. jejuni was the only Campylobacter species isolated. The Salmonella serovars were 14 Enteritidis, two Typhimurium, one Haydar/Istanbul, and one Galiema. One $S$. enterica subsp. arizonae was found, and in three cases, typing was not successful

significantly associated with any pathogen group, probably because of insufficient statistical power. Only 37 patients reported this symptom, 16 of which had some infection detected. Associated respiratory symptoms were reported by 125 patients whose pathogen distribution was similar to that seen in the whole group: viral, bacterial, and parasitic agents were detected in 36,15 , and 11 cases, respectively.

Information about patients' recent travel history ( $\leq 7$ days preceding the onset of illness) and diarrheal illness among family members, friends, and co-workers was available for
Fig. 1 a Proportions of patients who had bacterial, parasitic, or viral agents detected in the present study. b-d The proportions of patients in the various age groups who had selected pathogens in previous reports and the present study. $E$, English study (extracted from Amar et al. 2007 [12]); D, Dutch study (de Wit et al. 2001 [8]); $E R e$, English re-examination study (Amar et al. 2007 [12]); $I$, present Icelandic study
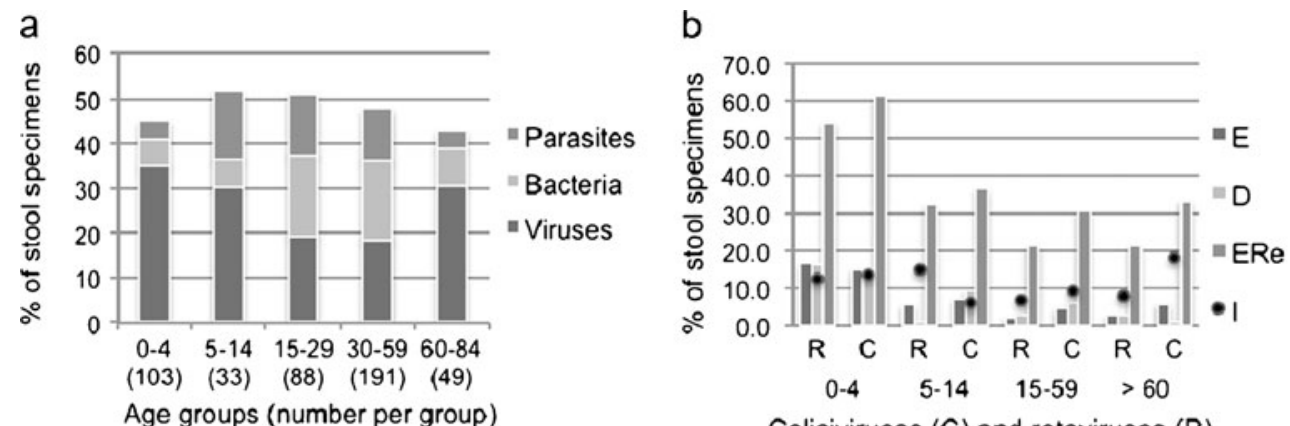

Caliciviruses (C) and rotaviruses (R)
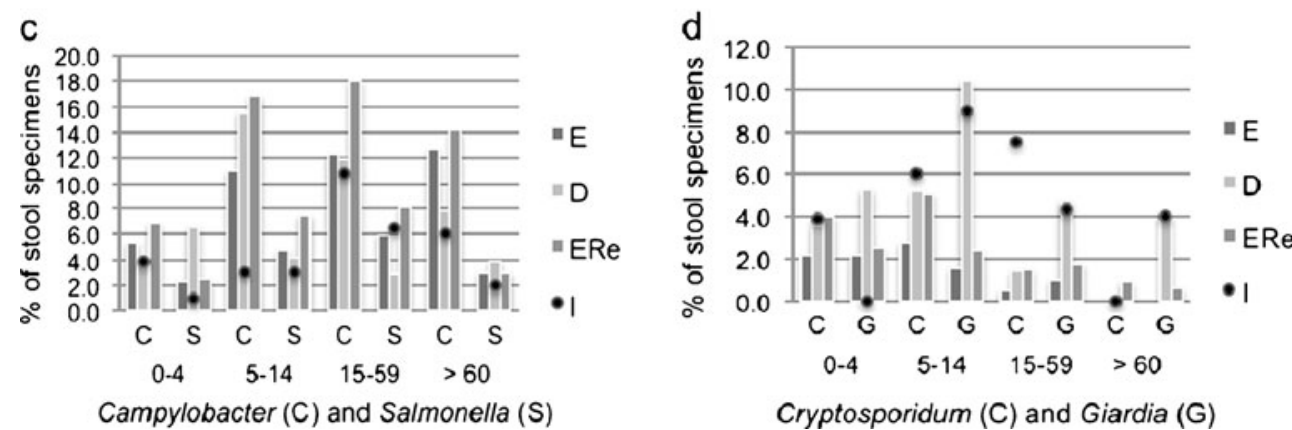

Cryptosporidum (C) and Giardia (G) 
Table 2 Multivariate analysis of the association of illness characteristics with pathogen groups

\begin{tabular}{|c|c|c|c|c|c|c|c|c|c|}
\hline \multirow{3}{*}{$\begin{array}{l}\text { Illness characteristics } \\
\text { (number of patients) }\end{array}$} & \multicolumn{9}{|c|}{ Number of patients with illness characteristics and odds ratios (OR) with $95 \%$ confidence intervals $(\mathrm{CI})$ for pathogens } \\
\hline & \multicolumn{2}{|c|}{ Viral pathogens } & \multicolumn{2}{|c|}{ Bacterial pathogens } & \multicolumn{2}{|c|}{ Parasitic pathogens } & \multicolumn{2}{|c|}{ Any pathogen } & \multirow{2}{*}{$\begin{array}{l}\text { No pathogen } \\
\text { No. }\end{array}$} \\
\hline & No. & $\mathrm{OR}(\mathrm{CI})$ & No. & $\mathrm{OR}(\mathrm{CI})$ & No. & OR (CI) & No. & OR (CI) & \\
\hline Vomiting (445) & 64 & $4.08(2.45-6.79)$ & 16 & - & 19 & - & 99 & $\begin{array}{l}2.11 \\
\quad(1.33-3.37)\end{array}$ & 67 \\
\hline Abdominal pain (412) & 73 & - & 44 & - & 36 & $\begin{array}{l}4.13 \\
\quad(0.96-17.81)\end{array}$ & 153 & & 173 \\
\hline Rectal pain (393) & 18 & - & 18 & $\begin{array}{l}2.48 \\
\quad(1.22-5.04)\end{array}$ & 8 & - & 44 & & 40 \\
\hline Fever (416) & 54 & - & 39 & $\begin{array}{l}5.7 \\
\quad(2.67-12.1)\end{array}$ & 12 & - & 105 & $\begin{array}{l}1.94 \\
\quad(1.23-3.05)\end{array}$ & 73 \\
\hline $\begin{array}{l}\text { Duration of illness } \\
>7 \text { days }(452)\end{array}$ & 11 & $0.8(0.74-0.87)$ & 13 & - & 28 & $\begin{array}{l}1.21 \\
\quad(1.12-1.32)\end{array}$ & 52 & $\begin{array}{l}0.93 \\
(0.88-0.98)\end{array}$ & 98 \\
\hline
\end{tabular}

${ }^{a}$ The total number for each variable represents patients who completed the questionnaire with regard to that variable

Empty cells: variable not used in the model because of an insignificant association with the pathogen group

more than $95 \%$ of the 452 patients in whom simple or no infections were detected. Bacterial pathogens were more frequent in those who had traveled abroad than those who had not $(32.6 \%$ of 92 patients vs. $7.3 \%$ of 356 patients, $p<0.001)$, and viral pathogens were less frequent in travelers $(8.7 \%$ vs. $26.7 \%, p<0.001)$. Bacterial pathogens were also more frequent in those who had traveled in Iceland only compared to those who had not $(26.9 \%$ of 52 patients vs. $10.6 \%$ of 378 patients, $p=0.001)$. When travel history was extended to 6 weeks or children under the age of 5 years were excluded, these differences remained significant. Illness in the patients' entourage was significantly associated with a higher likelihood of being infected; $51.6 \%$ of 188 patients with illness in entourage had a pathogen detected versus $38.5 \%$ of 244 patients without $(p=0.007)$. A tendency towards an association was seen for viruses, but it was not significant; $26.6 \%$ of 188 infected patients had illness in

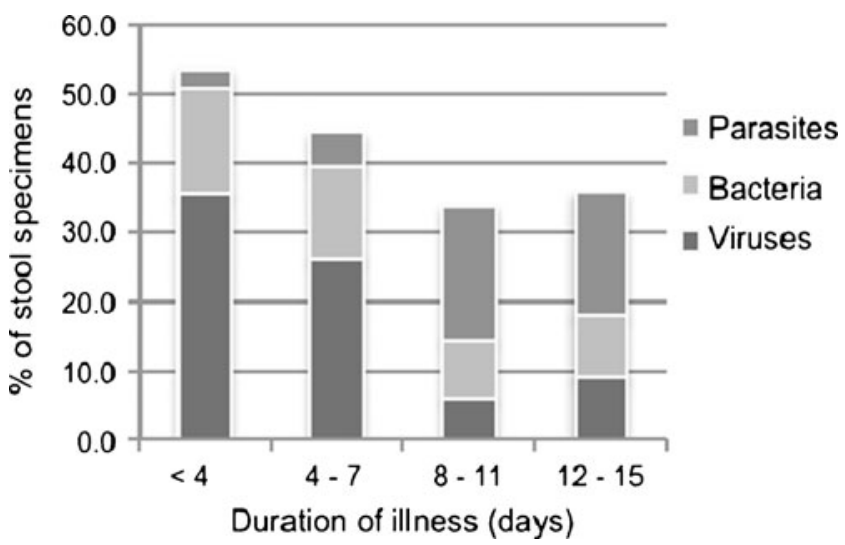

Fig. 2 Pathogen groups detected at various intervals after the onset of illness entourage versus $19.3 \%$ of 244 patients without ( $p=0.07$ ). Information about patients' occupations was available in 435 cases. Among the 16 food handlers and 43 healthcare or kindergarten workers, 12, 12, and 6 cases of viral, bacterial, and parasitic agents were detected, respectively.

We examined the diagnostic yield of stool tests in our laboratories for the period 2004-2007 after excluding the 429 study patients. The average proportions of patients who had positive stool tests were $8,5.5$, and at least $26 \%$ out of 10,518 , 4,244, and 3,095 patients who had bacterial, parasitological, and virological tests performed, respectively. Pathogens which were routinely searched for were the same as those addressed in this study, except that stools were tested for Cryptosporidium species upon special request and for astro-, adeno-, and rotaviruses in all children $\leq 12$ years and upon request. The study patients had a significantly higher yield, compared to routinely tested patients, of pathogenic bacteria $(12.4 \%, p=0.001)$ and parasites $(7.9 \%, p=0.038)$, but not of viruses $(23.8 \%, p=0.32)$.

\section{Discussion}

This is the first Nordic study on the etiology of infectious diarrheal disease in patients of all ages who consulted GP clinics. It is also one of few studies that included adult patients $[7,8,13,14]$. The results provide information about the etiology of diarrhea in this patient population and support existing data on the predictive value of illness characteristics, age, and travel with regard to the pathogens detected. In our analysis of the latter, we chose to group related pathogens, instead of assessing associations with individual organisms, which had the benefit of raising the power of the statistical analyses. Our choice was supported 
by well-accepted illness characteristics of the various infections and published studies on symptom-pathogen association $[8,15,16]$, and reflects the common clinical and laboratory practice of subjecting stool specimens to a battery of tests for organisms in the same pathogen group.

Age groups and pathogen detection rates

The detection rates for various pathogen groups were in agreement with other studies in Western Europe [7, 8, 14, 17, 18], with some exceptions (Fig. 1b-d). Viruses are usually the dominant pathogens in children $\leq 4$ years old, and the distribution of pathogen groups in the 5-14 years age group is similar to that seen in adults, in which bacteria and parasites become more frequent. In our study, viruses were still found in $30 \%$ of the 5-14 years age group that maintained the high frequency of rotavirus infections seen in the youngest age group. A bias cannot be excluded due to the small number of patients in this age group. However, children's exposure to each other within large families (due to a relatively high birth rate in Iceland) and universal kindergarten attendance might also favor viral transmission. Furthermore, viruses were also the dominating pathogen group in the elderly ( $\geq 60$ years old), mostly because of caliciviruses that were seen in $18 \%$ of patients in this age group. This could be explained by a close-knit family environment where the elderly frequently look after their grandchildren. C. difficile was found in $0,1.7$, and $4.6 \%$ of patients in other GP clinic-based studies from Germany, England, and Austria, respectively [7, 13, 14]. Information about antibiotic use was either not available [7] or reported in only a minority of cases [14]. We found $C$. difficile toxin in $2.5 \%$ of the 79 patients who were tested. Antibiotic use or hospitalization during the 4 weeks that preceded the illness was reported by 8 of the 79 patients, but not by those who tested positive. Although $C$. difficile-associated diarrhea is not among the most common causes of communityacquired diarrhea, it does occur in the absence of recognized risk factors and may, thus, be overlooked by physicians when they request stool tests. The detection rates of parasites appear to vary greatly among the studies presented in Fig. 1d, and this could be partially explained by different study designs. The English study [7, 12] included patients with vomiting or diarrhea that had lasted $\leq 2$ weeks, whereas our study and the Dutch investigation [8] included only diarrhea cases, and the latter did not have a time limit on the duration of diarrhea. Vomiting is not a prominent sign in parasitic infections and Giardia infections tend to last for more than two weeks. Cryptosporidium species turned out to be as common as Salmonella serotypes in our study, even when the likely outbreak in 2003 was excluded. Compared to the English and Dutch studies, a high rate of Cryptosporidium detection was seen in the group of patients aged 15-
59 years. As a result of these findings, our routine laboratory practices were modified to include a test for the parasite on every stool specimen submitted for parasitological testing.

Factors associated with pathogen groups

Our analysis of the association between patient-related factors and pathogen groups confirmed some of the findings from the Dutch study [8]. Vomiting was, thus, associated with viral pathogens, fever with bacterial pathogens, and duration of illness $>7$ days was positively associated with parasitic agents and inversely with viral agents. Although inquiry about rectal pain may not be a routine practice in the evaluation of diarrheic patients, it is seen in inflammatory colon diseases and was, in our study, found to be associated with bacterial agents. In addition, there was a tendency towards an association between abdominal pain and parasitic infections on one hand, and between incremental age and bacterial agents on the other. Few patients reported bloody stools in our study and that might explain the lack of association with bacterial agents. Both local and foreign travel was associated with bacterial pathogens, which are often food- and waterborne. Likewise, data from the English study showed that foreign travel and eating chicken at a restaurant were significantly associated with Campylobacter infections [19], and foreign travel was also associated with bacterial diarrhea in Denmark [20]. In contrast, viral pathogens are more likely to be transmitted by person-to-person spread, and the inverse relationship observed between viruses and travel suggests that patients acquire these infections while staying home with young children and the elderly, who are the most likely to be infected. Contact with symptomatic persons has been found to be significantly associated with viral diarrhea in other studies $[13,20]$.

\section{Detection yield and guidelines}

The pathogen detection yield was $45.5 \%$, which is similar to the values of $23-55 \%$ found in GP-based or population cohort studies that relied mostly on traditional laboratory methods [2, 7, 8, 14, 21]. The English re-examination study [12] increased the positivity rate to $75 \%$ by adding molecular methods to the traditional ones. Similarly, a German study on hospitalized patients with communityacquired gastroenteritis obtained a yield of about $80 \%$ by adding bacterial serology to conventional methods, thus, greatly enhancing the detection of Campylobacter infections [22]. Since the addition of a test method is not always possible because of cost issues, it is worth trying to improve the yield of current testing by enhancing the performance of older methods or replacing them with new ones. And, last, but not least, it is important to guide 
physicians towards an efficient selective stool testing through the better use of illness characteristics, other patient-related factors, and regional epidemiological data.

Various factors influence symptoms and signs, including pathogen and host factors, infectious load, and mixed infections. The English re-examination study showed that about $40 \%$ of symptomatic patients harbored mixed infections [12], which complicate the attribution of specific symptoms to individual pathogens. Some of these mixed infections, and presumed mono-infections, are detected by highly sensitive tests that may overestimate the disease burden of a pathogen that is not necessarily the cause of the present illness. To correct for this, Phillips et al. used viral load in an RT-PCR test to improve the estimation of norovirus disease as opposed to an asymptomatic carriage [23]. In the absence of such an approach, etiological studies that use methods of variable sensitivity for different pathogens will lead to an overestimate or underestimate of the true disease burden of these pathogens. It is possible that, due to the lack of sensitivity inherent in most of the current routine tests, they would usually detect those pathogens that are high in number and, therefore, more likely to be the cause of symptoms and, depending on the organism, amenable to therapy.

Requests for stool testing should be guided by illness characteristics, underlying condition, and exposure risks, including recent travel, outbreak situations, and occupation. Existing guidelines recommend tests for bacteria or parasites in patients who are immunocompromised, have severe or long-standing illness, have traveled abroad, or work as food handlers or caregivers [24, 25]. However, the laboratory confirmation of viral gastroenteritis would rarely be done if the guidelines are followed, although it has a role in heralding seasonal peaks for some viral agents, may help prevent outbreaks in institutions, and provides valuable information about the local epidemiology. Moreover, viruses are among the top four pathogens in adult patients and the most common ones in children who require hospitalization for severe community-acquired diarrhea $[22,26]$. And, finally, the occurrence of mixed infections suggests that a wide test panel should be applied in some cases, such as for food handlers. Selective testing is necessary for cost efficiency and is widely practiced [1, 27-29]. However, some selection practices suggest a misunderstanding of the purpose of testing and can be harmful. A survey of physicians' practices in the USA showing a decreased likelihood of stool testing for potential outbreak cases is a good example [28]. Our study indicated that the use of simple inclusion and exclusion criteria significantly increased the detection rate of bacteria and parasites compared to those obtained in routine stool tests. The modification of selection criteria could increase the rate even further. As an example, we tested the predictability of several illness characteristics observed in our study by looking at the 313 patients who had been ill for $\leq 7$ days. Forty-eight of these had bacterial pathogens; however, for the 94 who reported "present" for vomiting and "absent" or "not known" for bloody stool, rectal pain, and travel abroad, only $5(10 \%)$ bacterial infections were missed. As data on pathogen associations with symptoms, travel, age, and other factors accumulate and meta-analyses become feasible, a further refinement of existing guidelines and the creation of algorithms could enhance patient safety and cost efficiency. To further aid physicians in choosing stool tests, guidelines should include available information about the regional epidemiology, since the prevalence of various pathogens may differ across regions.

\section{Limitations of the study}

First, the pathogen detection yield was limited by testing only one sample per patient and searching for only the most common pathogens in community-acquired diarrhea, and not for agents such as enterovirulent $E$. coli other than $E$. coli O157. Second, the assessment of illness characteristics versus pathogen groups relied on patients' subjective evaluation of their illness. Although this probably reflects real-life situations in clinical practice, the reliability of the reported symptoms and signs could be enhanced through interview-based questionnaires or thoroughly tested selfadministered questionnaires. Third, like other clinic-based studies, the information on the causes of diarrhea in our study is limited to patients who seek healthcare, and is, thus, subject to a certain selection bias [6]. Fourth, unlike previous studies $[7,8,13,14]$, ours excluded patients who had vomiting without diarrhea or illness of more than two weeks' duration, and, therefore, the relative proportion of viral and parasitic agents in our study may not reflect fully the epidemiology of gastroenteritis cases that present to GPs. And, finally, we grouped related pathogens in order to increase statistical power and reflect common request and laboratory practices. While we are aware that the nonspecific nature of most symptoms affects the results of the analysis, we believe that this can be partly corrected for by including other factors, such as the duration of symptoms, age, and travel history.

\section{Conclusion}

Our results support the main findings from the few reports available on the etiology of diarrhea in patients of all age groups who seek general practice (GP) services in developed countries [7, 8, 13, 14]. However, they also suggest the existence of regional differences that might be partly explained by societal composition. In light of the individual 
and societal importance of diarrheal disease, and the high cost of inefficient laboratory testing, we believe that clear and simple guidelines should be implemented, regularly updated, and tested against no-guideline-based practice. Although studies like ours are expensive, they are indispensable for the mapping of regional epidemiology and the choice of laboratory methods, and, when integrated into effective guidelines, may lower morbidity and cost in the long run.

Acknowledgments This study was, in part, funded by grants from Landspítali University Hospital, The Icelandic Centre for Research, and The University of Iceland. We would like to thank Örn Ólafsson for the assistance with the statistical analysis of this study, and the general practitioners in the Icelandic Diarrhea Study Group: Anna Kr. Jóhannsdóttir, Björn Guðmundsson, Björn Hjálmarsson, Egill R. Sigurgeirsson, Einar Eyjólfsson, Friðrik V. Guðjónsson, Guðbjörg Sigurgeirsdóttir, Guðjón I. Geirmundsson, Guðmundur Olgeirsson, Hannes Hrafnkelsson, Hildur Svavarsdóttir, Hilmir Jóhannsson, Hjörtur P. Hauksson, Hörður Björnsson, Jórunn V. Valgarðsdóttir, Kristjana Kjartansdóttir, Marianne B. Nielsen, Óskar Reykdalsson, Páll Porgeirsson, Páll Porsteinsson, Pétur Pétursson, Reynir Porsteinsson, Sigríður D. Magnúsdóttir, Sigurður V. Guðjónsson, Stefán B. Matthíasson, Stefán Björnsson, Víðir Óskarsson, Pórarinn H. Harðarson, Pórir V. Pórisson, and Pórir Pórhallsson.

Conflict of interest The authors declare that they have no conflict of interest.

\section{References}

1. Wheeler JG, Sethi D, Cowden JM, Wall PG, Rodrigues LC, Tompkins DS, Hudson MJ, Roderick PJ (1999) Study of infectious intestinal disease in England: rates in the community, presenting to general practice, and reported to national surveillance. The Infectious Intestinal Disease Study Executive. BMJ 318:1046-1050

2. de Wit MA, Koopmans MP, Kortbeek LM, Wannet WJ, Vinjé J, van Leusden F, Bartelds AI, van Duynhoven YT (2001) Sensor, a population-based cohort study on gastroenteritis in the Netherlands: incidence and etiology. Am J Epidemiol 154:666-674

3. de Wit MA, Hoogenboom-Verdegaal AM, Goosen ES, Sprenger MJ, Borgdorff MW (2000) A population-based longitudinal study on the incidence and disease burden of gastroenteritis and Campylobacter and Salmonella infection in four regions of The Netherlands. Eur J Epidemiol 16:713-718

4. Hoogenboom-Verdegaal AM, de Jong JC, During M, Hoogenveen R, Hoekstra JA (1994) Community-based study of the incidence of gastrointestinal diseases in The Netherlands. Epidemiol Infect 112:481-487

5. Imhoff B, Morse D, Shiferaw B, Hawkins M, Vugia D, Lance-Parker S, Hadler J, Medus C, Kennedy M, Moore MR, Van Gilder T; Emerging Infections Program FoodNet Working Group (2004) Burden of self-reported acute diarrheal illness in FoodNet surveillance areas, 1998-1999. Clin Infect Dis 38(Suppl 3):S219-S226

6. Tam CC, Rodrigues LC, O'Brien SJ (2003) The study of infectious intestinal disease in England: what risk factors for presentation to general practice tell us about potential for selection bias in case-control studies of reported cases of diarrhoea. Int J Epidemiol 32:99-105

7. Tompkins DS, Hudson MJ, Smith HR, Eglin RP, Wheeler JG, Brett MM, Owen RJ, Brazier JS, Cumberland P, King V, Cook PE
(1999) A study of infectious intestinal disease in England: microbiological findings in cases and controls. Commun Dis Public Health 2:108-113

8. de Wit MA, Koopmans MP, Kortbeek LM, van Leeuwen NJ, Vinjé J, van Duynhoven YT (2001) Etiology of gastroenteritis in sentinel general practices in the Netherlands. Clin Infect Dis 33:280-288

9. Mead PS, Slutsker L, Dietz V, McCaig LF, Bresee JS, Shapiro C, Griffin PM, Tauxe RV (1999) Food-related illness and death in the United States. Emerg Infect Dis 5:607-625

10. Buzby JC, Roberts T, Jordan Lin C-T, MacDonald JM (1996) Bacterial foodborne disease: medical costs and productivity losses. Economic Research Service, U.S. Department of Agriculture. Agricultural Economics Report No. AER741. 1996. Available online at: http://www.ers.usda.gov/Publications/AER741/. Accessed 8 June 2011

11. Le Guyader F, Estes MK, Hardy ME, Neill FH, Green J, Brown DW, Atmar RL (1996) Evaluation of a degenerate primer for the PCR detection of human caliciviruses. Arch Virol 141:2225-2235

12. Amar CF, East CL, Gray J, Iturriza-Gomara M, Maclure EA, McLauchlin J (2007) Detection by PCR of eight groups of enteric pathogens in 4,627 faecal samples: re-examination of the English case-control Infectious Intestinal Disease Study (1993-1996). Eur J Clin Microbiol Infect Dis 26:311-323

13. Karsten C, Baumgarte S, Friedrich AW, von Eiff C, Becker K, Wosniok W, Ammon A, Bockemühl J, Karch H, Huppertz HI (2009) Incidence and risk factors for community-acquired acute gastroenteritis in north-west Germany in 2004. Eur J Clin Microbiol Infect Dis 28:935-943

14. Huhulescu S, Kiss R, Brettlecker M, Cerny RJ, Hess C, Wewalka G, Allerberger F (2009) Etiology of acute gastroenteritis in three sentinel general practices, Austria 2007. Infection 37:103-108

15. Pang XL, Honma S, Nakata S, Vesikari T (2000) Human caliciviruses in acute gastroenteritis of young children in the community. J Infect Dis 181(Suppl 2):S288-S294

16. Svenungsson B, Lagergren Å, Ekwall E, Evengård B, Hedlund KO, Kärnell A, Löfdahl S, Svensson L, Weintraub A (2000) Enteropathogens in adult patients with diarrhea and healthy control subjects: a 1-year prospective study in a Swedish clinic for infectious diseases. Clin Infect Dis 30:770-778

17. Rosenfeldt V, Vesikari T, Pang XL, Zeng SQ, Tvede M, Paerregaard A (2005) Viral etiology and incidence of acute gastroenteritis in young children attending day-care centers. Pediatr Infect Dis J 24:962-965

18. Olesen B, Neimann J, Böttiger B, Ethelberg S, Schiellerup P, Jensen C, Helms M, Scheutz F, Olsen KE, Krogfelt K, Petersen E, Mølbak K, Gerner-Smidt P (2005) Etiology of diarrhea in young children in Denmark: a case-control study. J Clin Microbiol 43:3636-3641

19. Rodrigues LC, Cowden JM, Wheeler JG, Sethi D, Wall PG, Cumberland P, Tompkins DS, Hudson MJ, Roberts JA, Roderick PJ (2001) The study of infectious intestinal disease in England: risk factors for cases of infectious intestinal disease with Campylobacter jejuni infection. Epidemiol Infect 127:185-193

20. Ethelberg S, Olesen B, Neimann J, Schiellerup P, Helms M, Jensen C, Böttiger B, Olsen KE, Scheutz F, Gerner-Smidt P, Mølbak K (2006) Risk factors for diarrhea among children in an industrialized country. Epidemiology 17:24-30

21. Sinclair MI, Hellard ME, Wolfe R, Mitakakis TZ, Leder K, Fairley CK (2005) Pathogens causing community gastroenteritis in Australia. J Gastroenterol Hepatol 20:1685-1690

22. Jansen A, Stark K, Kunkel J, Schreier E, Ignatius R, Liesenfeld O, Werber D, Göbel UB, Zeitz M, Schneider T (2008) Aetiology of community-acquired, acute gastroenteritis in hospitalised adults: a prospective cohort study. BMC Infect Dis 8:143

23. Phillips G, Tam CC, Conti S, Rodrigues LC, Brown D, IturrizaGomara M, Gray J, Lopman B (2010) Community incidence of 
norovirus-associated infectious intestinal disease in England: improved estimates using viral load for norovirus diagnosis. Am J Epidemiol 171:1014-1022

24. National Institute for Health and Clinical Excellence (2009) Diarrhoea and vomiting caused by gastroenteritis: diagnosis, assessment and management in children younger than 5 years. Clinical guidelines CG84. Available online at: http://www.nice.org. uk/nicemedia/pdf/CG84FullGuideline.pdf. Accessed 8 June 2011

25. Guerrant RL, Van Gilder T, Steiner TS, Thielman NM, Slutsker L, Tauxe RV, Hennessy T, Griffin PM, DuPont H, Sack RB, Tarr P, Neill M, Nachamkin I, Reller LB, Osterholm MT, Bennish ML, Pickering LK; Infectious Diseases Society of America (2001) Practice guidelines for the management of infectious diarrhea. Clin Infect Dis 32:331-351

26. Malek MA, Curns AT, Holman RC, Fischer TK, Bresee JS, Glass RI, Steiner CA, Parashar UD (2006) Diarrhea- and rotavirus-associated hospitalizations among children less than 5 years of age: United States, 1997 and 2000. Pediatrics 117:1887-1892

27. Noone A, Cossar J, Spence G, Allardice G, Girdwood T (2000) Gastrointestinal infections presenting in general practice in Scotland. Health Bull (Edinb) 58:286-300

28. Hennessy TW, Marcus R, Deneen V, Reddy S, Vugia D, Townes J, Bardsley M, Swerdlow D, Angulo FJ; Emerging Infections Program FoodNet Working Group (2004) Survey of physician diagnostic practices for patients with acute diarrhea: clinical and public health implications. Clin Infect Dis 38 (Suppl 3):S203-S211

29. van den Brandhof WE, Bartelds AI, Koopmans MP, van Duynhoven YT (2006) General practitioner practices in requesting laboratory tests for patients with gastroenteritis in the Netherlands, 2001-2002. BMC Fam Pract 7:56 